\title{
EUGENETIKA EN DIE MEDIES-GENETIESE BEHANDELING VAN DIE MENS
}

In hierdie artikelreeks word eerstens gepoog om die huidige stand van navorsing en wetenskaplike bespreking aangaande eugenetika en die mediesgenetiese behandeling van die mens op 'n saaklike wyse weer te gee. Hierdie benadering word as 'n noodsaaklike voorvereiste beskou alvorens daar tweedens tot ' $n$ inleidende moreel-etiese bespreking van dié onderwerp as geheel oorgegaan word.

\section{INLEIDING}

Die idee van 'n biologies-tegnies gemanipuleerde mensdom is gebore uit die klassieke idealisme van ouds. Wat destyds as ' $n$ utopie beskou is, is vandag nader aan verwesenliking as wat $\mathrm{Plato}$ kon vooruitsien. Die ideaal van 'n kwalitatiewe verbetering van die mens deur middel van kunsmatige maatreëls, $d \mathbf{w}$ s eugenetika, is deur die vooruitgang op veral twee terreine besonder bevorder. Aan die een kant is dit die humanisme in al sy fasette, soos deur die Renaissance aan ons nagelaat, wat aan die mens en sy idealistiese strewe 'n sentrale plek toegeken het. Aan die ander kant het die bevindinge van Darwin (1859) - dat naamlik biologiese verandering of evolusie deur natuurlike seleksie teweeggebring word al hoe wyer kringe begin trek. Voortspuitend uit hierdie voorafgaande ontwikkeling het Sir Francis Galton (1822 1911), vader van die eugenetika en ook skepper van die naam (eugenes: grieks vir welgeskape), gestalte aan n nuwe toegepaste medies-genetiese vakgebied gegee.

"Man is gifted with pity and other kindly feelings; he has also the power of preventing many kinds of suffering. I conceive it to fall well within his province to replace Natural Selection by other proc sses that are more merciful and not less effective. This is precisely the aim of eugenics." (Galton, 1908)

Eugenetika het sy ontstaan dus aan uiteenlopende ontwikkelinge te danke.

Die bestaansreg van openbare wetenskapsbeoefening is gegrond op die voorwaarde dat dit vir die betrokke gemeenskap van waarde moet wees. Hieruit voortvloeiend moet beklemtoon word dat ook die verant-

* Met die skrywer van hierdie artikelreeks is ooreengekom dat nadat die reeirs klaar verskyn het, die Redaksie iemand sal vra om die vraagstuk van Eties-prinsipiële kant te bespreek.

Hoofred. 
woordelikheid $t$ o $v$ openbare wetenskapsbeoefening (minstens in nie-totalitêre state) in die laaste instansie in die gemeenskap gesetel moet wees. Daar sal vervolgens nader ondersoek moet word watter plek die spesifieke en toegepaste geneties-mediese vakwetenskap eugenetika in die wetenskapsbeoefening van'n gemeenskap inneem en watter verantwoordelikhede vir die gemeenskap daaruit voortvloei.

\section{WETENSKAPLIKE GRONDSLAG}

Die bevindinge voortvloeiend uit die beoefening van genetika vind meestal via toegepaste biologiese wetenskappe (byvoorbeeld medies en landboukundig) asook via die geesteswetenskappe hulle praktiese en teoretiese toepassing en kom daardeur die gemeenskap wa引rin dit beofen word ten goede. Eugenetika verteenwoordig $n$ verdere toegepaste vakterrein wat $t o v s y$ wetenskaplike benadering op genetiese bevindinge en gevolgtrekkings gegrond is. Hier is dit veral die beginsel van ' $n$ voortdurenaie biologiese ontwikkeling, of evolusie, asook die fenomenale vooruitgang op die terreine van die molekulêre genetika, sitogenetika en biochemiese genetika van die mens wat as basis vir eugenetika dien. In die praktiese en metodologiese toepassing skakel eugenetika baie nou met die mediese wetenskap. Trouens enige effektiewe toepassing van eugenetika sonder die tegniese en praktiese hantering deur medici is haas ondenkbaar.

\section{SOSIOLOGIES-IDEALISTIESE MOTIVERING}

Die algemene teoretiese doelstelling en motivering van eugenetika spruit voort uit die bydrae wat dit - volgens die voorstaanders daarvan - tot die voortgesette biologiese en psigiese welvaart van die gemeenskap maak. Daar word naamlik beklemtoon dat die mens 'n onvolmaakte biologiese (anatomies, fisiologies) en geestelike (sielkundig, sosiaal, kultureel) wese sou wees:

"Man, in fact, is in urgent need of further improvement."

(Huxley, 1962)

"Human nature has flaws too evident to be shrugged off."

(Dobzhansky, 1967)

Vanweë sodanige inherente kwantitatiewe en kwalitatiewe, liggaamlike en geestelike tekortkominge sou die mens met erfbare siektes, abnormaliteite en gebreke, 
asook met moreel-sedelike agterlikheid en verval te kampe hê.

$"$. . he (man) is a highly imperfect creature. He carries a heavy burden of genetic defects and imperfections. As a psychosocial organism, he has not undergone much improvement. Indeed, man is still very much an unfinished type, who clearly has actualized only a small fraction of his human potentialities. In addition, his generic deterioration is being rendered probable by his social, set-up, and definitely promoted by atomic fallout. Furthermore, his economic, technical and cultural progress is threatened by the high rate of increase of world population".

(Huxley, 1962)

Man as cancer of the planet. (Huxley, 1963)

Onderwyl die bestaande inherente biologiese en psigiese tekortkominge van die mens dus reeds op onheilspellende wyses tot uiting sou kom, word daar voorsien dat die biologiese en sielkundige eise wat aan die mens gestel sal word, in die toekoms baie hoër sal wees. Daar word aldus beklemtoon dat die geordende toekomstige vreedsame samelewing en inderdaad die letterlike oorlewing van die mensdom in gevaar gestel sou wees.

Teenoor die bestaande en toenemende toekomstige eise waarteen die mens in sy onvolmaaktheid reeds nie opgewasse sou wees nie, is sommige deskundiges van mening dat die mens bowendien ' $n$ kwalitatiewe en genetiese agteruitgang of "degenerasie" ondergaan. Die mensdom beleef by voorbeeld 'n ongekontroleerde en onselektiewe bevolkingsaanwas waar kwaliteit met kwantiteit vervang sou wees, terwyl baie min ouers en allermins die gemeenskappe gewillig sou wees om die verantwoordelikhede van hierdie laissez-faire situasie op hulle te neem.

"This trend (toward genetic deterioration) results partly from the fact that in these countries the easier reproductive course to follow, at least on the critical occasions, is that which leads to having children, while the more difficult course, the one calling for more self-control, foresight, conscientiousness and skill, is that by which conception is prevented. In this way the course of genetic selection tends to become reversed."

(Muller, 1965) 
Die huidige sosio-sielkundige klimaat in sommige bevolkings sou dus inderdaad 'n disgenetiese invloed uitoefen. Dit sou op sy beurt neerkom op'n ommekering van die gunstige eugenetiese ontwikkeling wat die mens gedurende voorafgaande millennia ondervind het.

\section{EUGENETIESE OPTREDE NOODSAAKIIK}

Teen hierdie agtergrond tree die vraag na die uitkoms en oplossing dringend na vore:

"The vital issue is whether mankind can rely on 'normal' biological forces for maintenance and improvement of its genetic patrimonies or whether man will have to take it upon himself to control and direct his own evolution as he will see fit in the light of his knowledge, wisdom and ethics."

(Dobzhansky, 1962)

Die standpunt van eugenetici ten opsigte van hierdie "vital issue" is onomwonde. Daar word gemeen dat baie van die genoemde probleme en tekortkominge alleen te bowe gekom sal kan word deur eugenetiese optrede, onder andere soos volg: die skepping van 'n inherent gesonder en aangepaster mens, wat oor verbeterde in tellektuele vermoëns en morele insigte asook oor'n effektiewer sosiale organisasie-, a an passings-en kultuurskeppingsvermoë beskik, en wat sy biologiese en psigologiese selfontwikkeling en self-verwesenliking bewustelik nastreef.

Vooraanstaande eugenetici soos veral Muller en Huxley beklemtoon dat die mens sy biologiese ontwikkeling in veel groter mate as tans in eie hande behoort te neem. Toegerus met bewustheid en rasionele verstand is die mens die enigste wese wat sy huidige situasie en sy toekomstige ontwikkeling in historiese perspektief kan sien. In die lig van hierdie vermoëns - so word gemeen behoort die mens alle pogings aan te wend om sy verdere ontwikkeling ("conscious, purposeful and planned") te beplan en om homself kwalitatief beter toe te rus. Die noodsaaklikheid hiervoor sou in die algemene morele en intellektuele eise wat daar reeds en in toekoms op die mens wag, geleë wees:

"For it is not only a reasonable aim to strive for a higher form among Man; it is a creed with the strength of a reli- 
gious conviction. It is not only a plain necessity of the new age of science which the genius of Man's mind has brought; it is in accordance with the long process of Nature, within which we may read the purpose of the world. And it is no small and selfish aim, for we work not only for ourselves but for a time to come. The long striving of our lives cannot only improve our present civilization, but may also enable future generations to live in an ever-unfolding wisdom and rising consciousness of the mission of Man.

(Anderson en Fernandes, 1969)

\section{IN DIENS VAN DIE GEMEENSKAP}

Naas die medies-genetiese en natuurwetenskaplike agtergrond van die eugenetika vorm die sosiaalkulturele en idealistiese motivering dus die uitstaande komponent waarop die bestaansreg van die eugenetika gegrond word. Die eugenetika - aldus die voorstaanders daarvan - maak aanspraak daarop dat dit aan lewensbelangrike behoeftes van die gemeenskap voorsien en dat dit uitkomste bied vir ernstige probleme wat met verloop van tyd dringend op die voorgrond sal tree ("... the moral imperative of Eugenics" - Huxley, 1962). Dienooreenkomstig is dit ook die gemeenskap (minstens in nietotalitêre state) by wie uiteindelik die verantwoordelikheid vir die toepassing - of gebrek aan toepassing - van die eugenetika berus. Inderdaad rus die verpligting op die gemeenskap (in die besonder op almal wat die belange daarvan op hulle harte dra) om minstens kennis en om standpunt in te neem to v die eugenetika en sy pleidooie.

\section{EUGENETIESE MAATREELS}

Sedert die dae van Galton wat die eerste praktiese pogings aangewend het om die vergesig van 'n verbeterde mensdom te verwesenlik, word daar twee metodologiese benaderings in die eugenetika onderskei; nl negatiewe eugenetika of die uitskakeling van ongewenste eienskappe en positiewe eugenetika of die vermeerdering van gewenste eienskappe. Teoreties kom albei hierdie benaderings op dieselfde beginsel neer, $\mathrm{nl}$ om deur selektiewe of differensiële voortplanting 'n kwalitatiewe verbetering van die mens na te streef. Hierdie benadering is ' $n$ direkte toepassing van 'n genetiese beginsel wat ook die grondslag van evolusie en die telingsleer vorm. 
In die bepleiting en toepassing van eugenetiese maatreëls moet onderskei word tussen 'n ouer, klassieke tydperk en 'n nuwe eugenetiese fase wat voorlopig alleen maar as 'n raamwerk van moontlikhede beskou moet word. Die pogings van die klassieke eugenetika het ongeveer in die tydperk tussen die afgelope wêreldoorloë hoogty gevier, waarna dit onsuksesvol en roemloos ten einde gegaan het. Die daaropvolgende tussenfase, waarin ons ook tans nog verkeer, is t o v eugenetika gekenmerk deur 'n algemene onsekerheid en rigtingloosheid, wat te wyte is aan die dilemma van onuitvoerbare maatreëls te midde van 'n situasie wat - volgens deskundiges eugenetiese optrede al hoe dringender noodsaak. Die idealistiese en humanistiese eugenetiese strewe wat voorheen die toneel oorheers het, het nou hoofsaaklik plek gemaak vir die individuele medies-tegniese behandeling en welvaart van die enkeling (pasiënt of potensiële pasiënt). Daarmee het dit skynbaar sy direkte eugenetiese implikasie verloor.

Die idealistiese doelstelling van die klassieke eugenetika van weleer is egter nog altyd latent aanwesig. Die moontlikhede van medies-tegniese behandelings wat vandag reeds toegepas word en wat op die drumpel staan om in die nabye toekoms toegepas te word, bied fenomenale geleenthede vir die uitskakeling van die vroeër probleme en vir die hernude ontplooing van die eugenetika. 'n Herlewing van die eugenetika, maar nou toegerus met heelwat addisionele kennis en met ongekende moontlikhede van die medies-tegniese behandeling staan op die drumpel van verwesenliking. Dit wil voorkom of die momentum van ontwikkeling hierdie keer voldoende sal wees om aan eugenetika mettertyd 'n permanente plek in die toekomstige samelewing te laat toekom.

\section{DEEL I : KLASSIEKE EUGENETIKA}

\section{EUGENETIESE DOELSTELLINGS}

Die algemene motiewe en ideale van eugenetika soos hierbo in breë trekke aangetoon kan hoofsaaklik na twee aanvullende en konkrete standpunte herlei word:

(a) Die mens ondervind ' $n$ kwalitatiewe agteruitgang to $v$ sy genetiese vermoëns en potensialiteite wat bekamp behoort te word. 
As aanvullend en/of alternatief word daar ook bepleit dat

(b) die mens ver bokant sy huidige peil van genetiese vermoëns en potensialiteite ontwikkel behoort te word, ten einde teen die eise van die toekoms opgewasse te wees.

Hierdie basiese en aanvullende doelstellings, asook die teoretiese moontlikhede van hulle verwesenliking en die probleme wat in verband daarmee ondervind word, sal vervolgens breedvoeriger ondersoek word.

1. Disgenetiese invloed van mediese behandeling Daar is mettertyd teoreties afgelei dat deur die vinnige en algemene vooruitgang van die mediese wetenskap al hoe meer mense wat onder andere juis vanweë genetiese swakhede, tekortkominge en abnormaliteite nie daartoe in staat sou wees nie (byvoorbeeld vroeë sterftes, steriliteit of andersins benadeel) toenemend in staat gestel word om te oorleef en om kinders van hulle eie te verwek. Nie alleen beteken die oorlewing van sulke persone 'n afname in die gemiddelde genetiese fiksheid of angepasthe:d van 'n bevolking nie, maar juis die genetiese swakhede en tekortkominge wat voorheen aanleiding tot 'n natuurlike uitskakeling (seleksie) gegee het, word nou danksy mediese behandeling voortgeplant, en in die bevolking geleidelik vermeerder.

Inderdaad sou 'n groot gedeelte van die huidige mensdom as gevolg van direkte of indirekte uitwerking van genetiese swakhede vandag nie aan die lewe wees nie (of nooit gebore gewees het nie) as dit nie was vir die mediese behandeling wat hulle voortgesette lewe en voortplanting moontlik gemaak het nie. (Die kindersterftes in Wes-Europa het byvoorbeeld vanaf omstreeks 1870 tot vandag toe van ongeveer 25-33\% tot ongeveer 3\% gedaal.) Die mens (veral in ontwikkelde lande) het dus waarskynlik 'n genetiese "degenerasie" of agteruitgang in tern.e van biologiese fiksheid of aangepastheid ondergaan.

Die disgenetiese uitwerking van mediese behandeling moet egter teen 'n breër agtergrond gesien word. Baie millennia gelede was die voorganger van die mens moontlik "optimaal" aan sy natuurlike omgewing aangepas en het hy met sy omgewing in 'n natuurlike 
genetiese ewewig verkeer. Enige genetiese swakheid of tekortkoming is destyds baie effektief en vinnig deur die genadelose proses van natuurlike seleksie uitgeskakel. Met die ontplooing van die vroegste vorms van beskawing, nl. die gebruik van vuur, van klipwerktuie, die bou en voorbereiding van skuilings, die verfyning van veldkosversameling, visvangs en jaggewoontes, die bekleding en beskerming van die liggaam, die domestikasie van plante en diere, die beoefening van landbou asook mettertyd die bydraes van toordokters en mediese praktyke (byvoorbeeld in die vroeë Egiptiese beskawings en elders), het die mens toenemend daarin geslaag om die natuur te oorkom en om homself in baie opsigte minder afhanklik daarvan te maak. Met sy kulturele vooruitgang het hy inderdaad die druk van natuurlike seleksie in sommige opsigte verlig en gelyktydig egter 'n genetiese agteruitgang aan die hand gewerk.

Die mediese wetenskap, as 'n vertakking van ons kulturele erfenis, gee dus aanleiding tot 'n proses van genetiese agteruitgang wat al vir baie millennia aan die gang is en wat bowendien slegs 'n uitvloeisel van die algemene kulturele en tegniese vooruitgang is. Die genetiese agteruitgang in terme van biologiese fiksheid of aangepastheid kan weliswaar beskou word as die "prys" wat die mens vir die algemene ontwikkeling van sy beskawingspeil en spesifiek vir sy medies-tegniese vooruitgang moet "betaal". Dit blyk verder hieruit dat die genetiese swakhede nie vinniger kan akkumuleer as wat die mediese vooruitgang dit toelaat nie (laasgenoemde is die oorsaaklike komponent). Indien die geweldige bevolkingsaanwas as 'n algemene maatstaaf geneem word, blyk dit dat die vooruitgang in beskawing, tegnologie en spesifiek die mediese ontwikkeling inderdaad heelwat vinniger was as wat die biologies-genetiese agteruitgang kon gewees het. (Waar die bevolkingsaanwas in ontwikkelde lande begin stagneer is dit eerder om sosiologiese en sielkundige redes en minder om biologies-genetiese tekortkominge.) Indien die mediese wetenskap dus ook in toekoms verder ontwikkel sal die mens die "luuksheid" van mediese terapie en kompensasie in plaas van natuurlike uitskakeling of seleksie en gevolglike nie-optimale natuurlike aangepastheid kan "bekostig". Indien die mediese vooruitgang uiteindelik sou stagneer of indien dit selfs'n agteruitgang sou beleef, is bogenoemde afleiding egter nie meer van toepassing nie. 
Uit bogenoemde volg dat die mens relatief tot sy ontwikkelende beskawingspeil en mediese vooruitgang geen genetiese agteruitgang ondervind het nie. In absolute terme ondervind hy egter wel 'n akkumulasie van genetiese swakhede en tekortkominge. Hierdie genetiese "degenerasie" is nog nooit kwantitatief bereken of empiries bepaal nie. Uit wiskundige berekeninge weet ons dat ' $n$ betekenisvolle kwalitatiewe genetiese agteruitgang a $\mathrm{g} v$ 'n geleidelike seleksieproses slegs na millennia waargeneem sal kan word. Hierteenoor kom die werklike grootskaalse impak van die mediese vooruitgang op die algemene oorlewings- en voortplantingspatroon van bevolkings as geheel eers gedurende die afgelope eeu tot uiting.

Nietemin is daar baie vooraanstaande deskundiges wat die omvang van die genetiese agteruitgang besonder $\mathrm{kri}$ ties beoordeel. Hulle wys met verontrusting op die toenemende afhanklikheid van kunsmatige mediese, tegniese en sosiale hulpmiddels om genetiese swakhede en tekortkominge te kompenseer. Die Nobelpryswenner Muller (1963) maak byvoorbeeld in sy betoog die stelling:

For society now comes effectively to the aid of those who for whatever reason, environmental or genetic, are physically, mentally or morally weaker than the average. ... this aid does usually succeed in saving them and their children up to and beyond the age of reproduction.

Enkele konkrete voorbeelde wat ter stawing van die argument van 'n genetiese agteruitgang van die mens dikwels aangehaal word, is soos volg: Ongeveer een uit elke 200 lewend gebore babas toon een of ander ernstige chromosomale abnormaliteit as gevolg waarvan hulle waarskynlik nie baie lank aan die lewe sou gebly het nie. Danksy die mediese hulp wat hierdie babas ontvang kan baie van hulle egter volwassenheid bereik. Gewoonlik word hierdie chromosoomafwykings egter nie oorgeërf nie (meestal weens steriliteit of letaliteit), maar die betrokke pasiënte word oorwegend in spesiale verpleeginrigtings gehou, waar hulle onderhoud deur groot finansiële bydraes deur die gemeenskap gewaarborg is. Verder word daar verwys na die toename van kleurblindheid, miopia, genetiese hartsiektes, hemofilia, muskulêre distrofie, sistiese pankreasfibrose (of mukoviscidosis 
wat reeds met 'n gemiddelde frekwensie van ongeveer 1 uit 2000 kinders voorkom), diabetes (hier word beklemtoon dat soveel as $5 \%$ van sommige bevolkings reeds 'n genetiese aanleg vir suikersiekte besit); skisofrenie (wat met 'n hoë frekwensie van ongeveer $1 \%$ in sommige bevolkings voorkom) en baie andere. Die algemene omvang van die voorkoms van genetiese siektes word ook weerspieël deur die raming dat ongeveer 1 uit 25-30 swarıgerskappe tot 'n baba met 'n ernstige aangebore defek of abnormaliteit aanleiding gee en dat ongeveer $50 \%$ van alle kinders in (Wes-Duitsland se) kinderklinieke aan siektes ly wat minstens gedeeltelik aan genetiese faktore toegeskryf word.

Die absolute toename van genetiese siektes en swakhede mag egter nie heeltemal ongekwalifiseerd beoordeel word nie. Een gesigspunt wat byvoorbeeld hier in aanmerking geneem moet word, is die kwessie van gebalanseerde polimorfismes. 'n Verdere keredenering van hierdie onderwerp vereis egter'n diepgaander studie van relevante genetiese vakliteratuur. Veral is heelwat meer navorsing noodsaaklik om hierdie netelige wisselwerking tussen "goeie" en "swak" genetiese kenmerke verder te ontrafel. Hier sal dus voorlopig volstaan moet word met die samevatting van twee teenstrydige standpunte. Teenoor die baie deskundiges wat meen dat die genetiese agteruitgang reeds ernstige afmetings aangeneem het en dat eugenetiese teenmaatreëls dringend oorweeg moet word, is daar diegene wat die situasie as onder beheer en nog as verantwoordbaar beskou.

2. Negatiewe korrelasie tussen gesinsgrootte en intelligensie

Galton het reeds in sy tyd gewys op die verskynsel dat uitstaande intellektuele vermoëns dikwels met redelike konstantheid in families oorgeërf word, en dat van dié begaafde families opvallend dikwels uitsterf. Sedertdien dui baie indirekte gevolgtrekkings daarop dat mense met gewenste intellektuele vermoëns (byvoorbeeld intelligensie, soos gemeet met 'n IK-toets) gemiddeld kleiner gesinne het as ander en omgekeerd. Hierdie negatiewe verband tussen intelligensie en voortplantingsspoed (oorsaak en gevolg word met dié empiriese waarneming nie bepaal nie) sou mettertyd dus aanleiding tot 'n vinniger toename van minder intelligente persone ten koste van 'n relatiewe afname van die intelligenter 
gedeelte in 'n bevolking gee. Die gemiddelde intelligensie van 'n bevolking behoort dus ingevolge bogenoemde disgenetiese effek met verloop van tyd te daal. Sommige van die waarnemings waarop hierdie indirekte afleiding gegrond word, sal hier egter vollediger ondersoek moet word.

Daar is in talryke opnames opgemerk dat sekere sosioekonomiese klasse heelwat stadiger voortplant (d w s minder kinders per gesin en /of groter generasie-intervalle as gevolg van laat huwelike) as ander. Hierdie sosioekonomiese klasse word onder andere gedefinieer in terme van opleidingspeil, inkomste en beroep. Van die vollediger statistiek uit verskeie lande wat Stern (1949) bespreek, word hier slegs 'n uittreksel ter illustrasie aangehaal: Voortplantingsspoed en opleidingspeil (gemiddelde vir steekproef 1,0 ): by moeders met universiteitsgraad 0,74 , by moeders met minder as 7 jaar skoolopleiding 1,39; voortplantingsspoed en inkomste (gemiddelde vir steekproef 1,0 ): by hoogste inkomstegroep 0,60 , by laagste inkomstegroep 1,37 ; voortplantingsspoed en beroep: by vakkundig gekwalifiseerde vaders 1,3, by ongeskoolde werkers 3,0 kinders per gesin.

Bogenoemde sosio-ekonomiese klasse staan op hulle beurt in 'n sekere verband met IK-prestasies. Sowel volwassenes in hoër sosio-ekonomiese klasse as hulle kinders, presteer in IK-toetse beter as verteenwoordigers van laer sosio-ekonomiese klasse. In 'n spesifieke steekproef is byvoorbeeld vasgestel dat kinders van vakkundig gekwalifiseerde vaders op 'n sekere sielkundige toetsingskaal ' $n$ telling van 51-52 behaal teenoor 31-32 by kinders van handearbeiders en van ongeskoolde vaders. In 'n ander opname was die IK van kinders wie se vaders ' $n$ professionele beroep uitoefen 125 teenoor 96 by kinders van ongeskoolde vaders. Die algemene gevolgtrekking wat uit hierdie reeks gekorreleerde waarnemings gemaak is, is dat die meer intelligente persone (in terme van IK-peile) in 'n gegewe tydsinterval minder kinders nalaat as die minder intelligente persone. Indien hierdie ongelyke voortplantingspoed oor geslagte sou aanhou, sal die aandeel van intelligente persone inderdaad verminder en ' $n$ afname in die gemiddelde intelligensiepeil van 'n bevolking meebring. 
Die probleme verbonde aan bogenoemde afleiding is voordie-handliggend. Die IK van 'n persoon is ' $n$ kwantitatiewe genetiese eienskap wat saamgestel is uit 'n genetiese komponent van variasie van nagenoeg 70-80\% en 'n nie-genetiese komponent van variasie van ongeveer 20 $30 \%$ wat van omgewingsinvloede afhanklik is. (Hierdie syfers is omstrede; die erfbaarheid van intelligensie is ' $n$ onderwerp van intensiewe navorsing.) In die praktyk is dit vervolgens die geval dat in die laer sosio-ekonomiese klasse die nie-genetiese invloede meestal nadelig vir die manifestering van 'n hoë IK blyk te wees (byvoorbeeld swak voeding, versorging en opleiding van kinders) en dus gedeeltelik vir die lae IK-tellings binne hierdie groep verantwoordelik mag wees.

'n Swaarwegender probleem is geleë in die feit dat 'n IKtoets slegs ' $n$ benaderde weerspieëling is van daardie moeilik definieerbare entiteit wat as "inherente intellektuele vermoë" slegs onvolledig omskryf kan word. Eensydige maar uitstaande intellektuele vermoëns (soos byvoorbeeld wiskundige, musikale, kunstige of letterkundige genialiteit of ander wenslike sielkundige eienskappe) sal sekerlik slegs in 'n baie geringe mate in die gewone IK-toetse hulle neerslag vind. Die baie addisionele en algemene probleme verbonde aan die interpretasie van IK-toetse kan hier alleen in die verbygaan genoem word. Hierbenewens is die indeling in sosioekonomiese klasse betreklik willekeurig gekies en baie dikwels bloot 'n kwessie van toeval.

Die gevolgtrekking is dat uit die aaneenskakeling van grof gekorreleerde en onnoukeurig gedefinieerde veranderlikes (gesinsgrootte - sosio-ekonomiese klas - IKprestasie) slegs indirekte en onbetroubare afleidings gemaak kan word. Spekulasies wat op hierdie benadering gegrond is, gee aanleiding tot die gevolgtrekking dat die gemiddelde IK-telling in sekere Westerse bevolkings met soveel as 2-5 punte (op die gewone IK-skaal) per generasie sou afneem. Die werklike kritiese toets is egter alleen moontlik wanneer ' $n$ spesifieke verteenwoordigende steekproef en hulle eie nageslagte vir generasies na mekaar en onder konstante, onveranderde omgewingstoestande (voorwaardes wat feitlik nie nagekom kan word nie) aan dieselfde IK-toets onderwerp word. 
Sover bekend, is alleen een toets uitgevoer wat naastenby aan bogenoemde vereistes voldoen. In 1932 is in Skotland 90000 skoolkinders aan 'n IK-toets onderwerp; dit is in 1947 met 'n soortgelyke toets op 70000 skoolkinders opgevolg. Die resultaat toon dat kinders van die latere steekproef 'n effens hoër IK-telling behaal het as kinders van dieselfde chronologiese ouderdom uit die vroeëre steekproef. Bykomstiglik is by hierdie toets egter ook opgelet dat die fisiologiese ontwikkeling by die latere steekproef verder gevorder was (puberteit was vroeër en liggaamslengte vir ouderdomsgroepe was groter) as by die vroeëre steekproef. Die IK-toename moet dus klaarblyklik ook in verband met die vinniger fisiologiese ontwikkeling beoordeel word. Die beweerde afname van die intelligensiepeil ingevolge 'n differensiële voortplantingspoed bly dus voorlopig empiries onbevestig.

'n Belangrike bykomstige argument wat hier in gedagte gehou moet word, is dat 'n betreklik groot deel van enige bevolking nie by waarnemings van hierdie aard betrek is nie. Dit is naamlik daardie groot getal van geestelik vertraagdes en swaksinniges wat in allerhande inrigtings van die samelewing geìsoleer is. Hulle voortplanting hoewel nie hèeltemal uitgeskakel nie - is gewoonlik baie laer as die gemiddelde van die bevolking (idiote en imbesiele is meestal steriel). Hierdie lae voortplantingspoed van die klas met die laagste IK-peil kompenseer in 'n mate vir die beweerde lae voortplantingspoed van die klasse met die hoër IK-peile. Bowendien beland (soos empiries waargeneem) 'n betreklik hoë aandeel van die kinders uit die lae sosio-ekonomiese klasse) uiteindelik in inrigtings waar hulle gewoonlik 'n onder-diegemiddelde getal kinders (indien enige) sal nalaat. Hier is dus feitlik 'n "natuurlike" seleksieproses aan die gang wat 'n gunstige eugenetiese uitwerking het.

Indien die verlaagde voortplanting van die onderste IKgroepe in aanmerking geneem word, dan blyk dit (volgens betreklik onlangse (1962) resultate) dat die gemiddelde aantal kinders vir gegewe IK-intervalle soos volg verdeel is: IK 0-55 (1,4 kinders); $56-70(2,5) ; 71-85(2,4)$; 86-100 (2,2); $101-115(2,3) ; 116-130(2,4)$; $131^{+}(3,0)$; of soos 'n ander opname toon: IK onder 70 (2,09 kinders), IK bo 130 (2,98 kinders). Hierdie resultate dui inderdaad daarop dat die voortplantingstempo by die hoër IK-groepe blykbaar nie laer is as by die laer IK-groepe nie. 
Hoe ook al die antwoord op die vraag, of die gemiddelde intelligensie in 'n bevolking mettertyd afneem of toeneem, uiteindelik mag lui, moet beklemtoon word dat die teenswoordige voortplantingspatroon maar'n onlangse ontwikkeling is. Die aanwending van voorbehoedmiddels en die bewuste toepassing van familiebeplanning sedert enkele dekades is tot vandag toe grootliks beperk tot die hoër sosio-ekonomiese klasse en kan dus waarskynlik aanleiding tot 'n differensiële voortplantingstempo gee. Die millennia voordat hierdie voortplantingspatroon in swang was, het hoë en lae sosioekonomiese klasse waarskynlik nie net ewe vinnig voortgeplant nie, maar die hoër en meer ontwikkelde klasse het sekerlik ook daarin geslaag om selfs meer kinders per gesin groot te maak as minder gegoede klasse met hulle hoër persentasie van kindersterftes. Trouens opnames wat in hierdie opsig by sekere bevolkings onderneem is, toon dat onder natuurlike toestande, vergelykbaar met dié van voorafgaande millennia, hoër ontwikkelde gesinne inderdaad vinniger voortplant as minder vooruitstrewende gesinne (vgl Osborn, 1968).

Die voortplantingspatroon van 'n bevolking is egter 'n veranderlike wat maklik op sosiologiese en sielkundige strominge reageer. Namate die aanwending van voorbehoedmiddels en die toepassing van familiebeplanning ook na die laer sosio-ekonomiese klasse uitgebrei kan word ('n kwessie van eugenetiese voorligting) kan verwag word dat die vermeende differensiële voortplantingspoed mettertyd geneutraliseer behoort te word. Bevindinge afkomstig vanaf ontwikkelde lande soos Engeland is in ooreenstemming met sodanige verwagting:

"As family planning spread, however, the situation changed and at present family size is on the whole increasing with intelligence, although there is still an undesirable bulge around IQ 85 to 95."

(News and Views, 1969b)

Samevattend blyk dit dus dat die beweerde algemene en ernstige disgenetiese effek voortvloeiend uit die hipotetiese negatiewe korrelasie tussen intelligensie en voortplantingspoed onbeslis blyk te wees. 


\section{Akkumulasie van nuwe mutasies}

Die skynbaar spontane verandering van 'n eenheid genetiese informasie, $\mathrm{d} \mathrm{m} \mathrm{v} \mathrm{mutasie,} \mathrm{gee} \mathrm{of} \mathrm{direk} \mathrm{of} \mathrm{eers}$ na 'n aantal generasies aanleiding tot ' $n$ veranderde fenotipiese kenmerk. Die oorgrote meerderheid van mutasies lei tot kenmerke wat in 'n minder of meerder mate nadelig vir die individu is waarin hulle tot uiting kom. Hulle word derhalwe vroeër of later deur natuurlike seleksie uitgeskakel en gee aanleiding tot 'n betreklik konstante wiskundige ewewigsverband tussen akkumulerende nuwe mutasies en seleksie. Dié ewewig kan versteur word deur of 'n verandering in die seleksie-intensiteit, of deur 'n verandering in die mutasiespoed. Juis 'n verhoging van die mutasiespoed word vandag toenemend as bykomstige oorsaak vir die verhoging in die frekwensie van nadelige gene in bevolkings aangevoer.

Deskundiges wys met besorgdheid op die hedendaagse vryelike beskikbaarstelling van mutageniese stowwe en die aanwending van ioniserende strale. Daar word geskat dat deur sodanige praktyke die gemiddelde mutasiespoed by die mens (tans ongeveer 35 nuwe puntmutasies per sigoot) reeds met 50-100\% (in verhouding tot die "natuurlike" mutasiespoed) sou toegeneem het. Die bydrae van nuwe nadelige mutasies tot die genetiese agteruitgang van 'n bevolking beoordeel Muller (1963) (aan wie die Nobelprys juis vanweë sy navorsing in verband met die mutageniese effek van $\mathrm{X}$-strale verleen is) soos volg:

"It is probable that some $20 \%$, if not more, of a human population has received a genetic impairment that arose by mutation in the immediately preceding generation, in addition to the far larger number of impairments inherited from earlier generations. If this is true, then, to avoid genetic deterioration, about $20 \%$ of the population who are more heavily laden with genetic defects that the average must in each generation fail to live until maturity or, if they do live, must fail to reproduce."

Die terrein van die mutagenese (of mutasieverwekking), asook die omvang en beoordeling van die disgenetiese effek daarvan is egter nog onvolledig ondersoek.

\section{Ekonomiese doelstelling}

'n Sekondêre argument waarop negatiewe eugenetiese maatreëls onder andere baie dikwels gegrond word, is 
ekonomies van aard. Daar word naamlik daarop gewys dat die inrigtings en tegniese fasiliteite vir die onderhoud en verpleging van abnormale persone 'n groot ekonomiese las in terme van fondse en mannekrag vir 'n gemeenskap beteken.

Konkrete kosteberekeninge in hierdie verband het uitgawes opgelewer wat nie oor die hoof gesien kan word nie. Naar word dan ook geëis dat die gemeenskap, wat as belastingbetalers hierdie uitgawes moet betaal daarop kan aandring om eugenetiese maatreëls in sekere gevalle verpligtend toegepas te kry.

\section{PROBLEME I $V$ M DIE TOEPASSING VAN EUGENETIESE MAATREELS}

Onafhanklik van die regverdigbaarheid van die eugenetiese doelstellings al dan sie het die klassieke eugenetika voor onoorkombar a praktiese problem $ə$ te staan gekom.

\section{Definisie van genetiese kenmerke}

Reeds Galton en sy opvolgers in verskeie lande het nadruklik gewys op nadelige aandoenings soos blindheid, doofheid, verstandelike vertraging en ander sielkundige abnormaliteite wat volgens hulle oortuiging mettertyd uitgeskakel behoort te word. By nadere ondersoek blyk dit dat hierdie eienskappe besonder kompleks en heterogeen van aard is. 'n Kenmerk soos byvoorbeeld "swaksinnigheid" kan enersyds veroorsaak word deur'n hele aantal verskillende en onafhanklike direkte genetiese defekte en indirekte potensialiteite. Andersyds mag dit die gevolg van nie-genetiese invloede, soos byvoorbeeld infeksies, beserings, vergiftiging ens. wees. Net so is die manifestasie van 'n gewensde kwantitatiewe eienskap soos intelligensie grootliks die uitkoms van 'n wisselwerking tussen die natuurlike genetiese aanleg en die omgewingstoestande waarin dit tot ontplooing kom.

Die effektiwiteit van eugenetiese maatreëls berus op die voorwaarde dat die fenotipe waarop die seleksie gerig is min of meer die direkte weergawe van 'n spesifieke genetiese samestelling moet wees. Hoe nouer en direkter sodanige oorsaaklike verband tussen genotipe en fenotipe des te effektiewer kan die seleksie toegepas word. Soos hierbo genoem, kan die oorsake van bogenoemde heterogene en komplekse eienskappe wat juis vir 
eugenetici van belang is slegs gedeeltelik na direkte genetiese faktore teruggevoer word. Dienooreenkomstig word die effektiwiteit van 'n eugenetiese seleksieprogram verlaag.

Met die beskikbare metodes van diagnosering is dit intussen dikwels moontlik om afsonderlike vorme van aandoenings binne 'n komplekse heterogene siektetoestand ten opsigte van die ten gronde liggende oorsake uit te ken. Nogtans word in baie eienskappe 'n soepele en ingewikkelde verband tussen genetiese aanleg en omgewingsinvloede gehandhaaf wat 'n betreklik ingewikkelde wiskundige en bevolkingsgenetiese benadering vereis. Indien die reeks gewenste en ongewenste kwantitatiewe fenotipiese eienskappe waarop eugenetici konsentreer in die lig van die afleiding hierbo ondersoek word, blyk dit dat eugenetiese maatreëls in die algemeen met die probleem van verlaagde doeltreffendheid te kampe het.

\section{Definisie van gewenste/ongewenste kenmerke}

Uit 'n ondersoek na die aard van die genetiese kenmerke blyk dit dat baie van hulle 'n kontinue fenotipiese variasie toon. Die verdeling van die IK-prestasies illustreer hierdie aspek besonder duidelik. IK-tellinge in 'n spesifieke interval rondom 100 word as "normaal" aanvaar. Terwyl IK-tellinge bo 130 aan "genieë" toegeskryf word en as besonder wenslik aanvaar word, geld dit al hoe minder vir afnemende IK-tellinge. Soortgelyke kontinue fenotipiese verspreiding kom ook by die meeste ander kenmerke wat vir eugenetiese doeleindes van belang mag wees, byvoorbeeld sienvermoë (grade van blindheid), hoorvermoë (grade van doofheid), asosialiteit, werkvermoë, gewelddadigheid en andere tot uiting. Dieselfde probleem kom ook by monogeniese kenmerke na vore. Enkel-faktor abnormaliteite gee naamlik ook aanleiding tot kontinue oorgange vanaf 'n feitlik onopvallende tot 'n drasties abnormale fenotipe. Die feit dat sodanige eienskappe bowendien deur uiterlike invloede en omstandighede veranderbaar en medies-tegnies kompenseerbaar is, maak die onderskeiding tussen "gewenste" en "ongewenste" toestande des te ingewikkelder. 


\section{Medies-tegniese kompensasie van gebrekkige genotipes}

In plaas daarvan om sy gebrekkige genotipe aan die eise van veranderende omgewingstoestande aan te pas, soos dit deur natuurlike en kunsmatige seleksie (in die geval van eugenetika) bewerkstellig word, is die mens in staat om deur bewustelike verandering of aanpassing van sy lewens- en omgewingstoestande - 'n vermoë wat die mens danksy sy beskawingspeil (medies, tegnies, ens.) feitlik na willekeur kan aanwend - sy gebrekkige genotipe te kompenseer.

'n Goed ontwikkelde sienvermoë byvoorbeeld, was millennia gelede 'n noodsaaklike natuurlike vereiste vir die voortbestaan van ons jagtende en swerwende voorouers. Die betreklik algemene verskynsels van kleurblindheid (wat terloops by primitiewe, jagtende en versamelende bevolkings groepe slegs met baie lae frekwensies voorkom, teelioor die baie hoër frekwensie daarvan by ontwikkelde Westerse bevolkingsgroepe), miopia, versiendheid, en bysiendheid (wat in ernstige vorm ekwivalent aan blindheid is) is vandag feitlik geen noemenswaardige belemmernis in ons huidige samelewing nie. Trouens sodanige genetiese of semi-genetiese gebreke word vandag so maklik en voortreflik gekompenseer dat 'n mens hulle al feitlik as "normaal" aanvaar. Die verskynsel van allergieë en neuroses (sielkundige en senuweeswakhede) is vandag baie algemene aandoenings wat volgens waarnemings vinnig toeneem en wat gedeeltelik na 'n genetiese aanleg teruggevoer word. Danksy die verligting en /of oorkoming daarvan deur medikasie kan dié gebrekkige genetiese aanlegte gekompenseer word.

By suikersiekte (diabetes) word die noodwendigheid van kompensasie ernstiger. Hierdie pasiënte is genoodsaak om hulle (grootliks) geneties-bepaalde hormonale tekort en wanbalans deur die gereelde toediening van insulien te kompenseer ten einde aan die lewe te bly. Die bekende bloeiersiekte, hemofilie, is 'n genetiese siektetoestand wat $t o v$ akuutheid van aandoening en moontlikheid van medies-tegniese kompensasie eweneens in hierdie kategorie val. Die drastiese aandoening by sommige babas met 'n spesifieke genetiese gebrek, naamlik galaktosemie gee aanleiding tot blindheid, lewersirrhose en swaksinnigheid tensy daardie babas nie baie konsekwent 
met 'n spesiale en duur dieet gevoed word nie. 'n Soortgelyke drastiese genetiese gebrek, wat onder andere tot ernstige swaksinnigheid lei, naamlik fenielketonurie (frekwensie is ongeveer een uit 10000 babas) kan eweneens danksy spesiale prosedures van kosvoorbereiding en met baie moeite gekompenseer word.

Hierdie reeks aandoenings kan sowel kwantitatief ( $d$ w $s$ aantal en verskeidenheid) asook kwalitatief ( $d \mathrm{w} s$ in terme van akuutheid) feitlik onbeperk aangevul word. Let op dat die reeks voorbeelde wat hierbo genoem word neerkom op 'n stygende gradient van akuutheid: van betreklik triviale gevalle tot drastiese abnormaliteite. Die noodwendigheid van terapeutiese kompensasie, die medies-tegniese moeite en die koste daaraan verbonde styg dienooreenkomstiglik. In die lig hiervan is dit inderdaad 'n netelige en onbegonne taak om die geleidelike oorgang van "gesond/normaal" na "siek/abnormaal" te definieer. Die eugenetika kom hier dikwels voor 'n dilemma te staan.

4. Effektiwiteit van seleksie by resessiewe kenmerke Selfs al sou dit moontlik wees om eensgesindheid, $t$ o $v$ die vraag of 'n spesifieke eienskap by 'n eugenetiese program ingesluit moet word; te kry, tree dikwels probleme met die effektiwiteit van seleksie op die voorgrond. Ter illustrasie van dié probleem kan die verskynsel van albinisme by die mens aangehaal word. Soos die meerderheid van alle genetiese gebreksiektes is albinisme 'n resessiewe kenmerk wat met 'n frekwensie van ongeveer een uit 20000 persone voorkom. Indien besluit sou word om albinisme in 'n bevolking uit te wis en dienooreenkomstig alle albino's in elke generasie voor puberteit sistematies te steriliseer, dan sou dit ongeveer 140 generasies (of ongeveer 4200 jaar) neem om die huidige geenfrekwensie van albinisme slegs met die helfte te verminder. 'n Verdere halvering van die geenfrekwensie sou nog 'n verdere 280 generasies (of ongeveer 8400 jaar) neem. Dieselfde wetmatigheid geld vir elke daaropvolgende interval waarin die geenfrekwensie halveer word. Die rede hiervoor is dat die seleksie alleen teen die homosigote (fenotipies albino's) gerig is, terwyl die heterosigoot-draers, wat fenotipies onopvallend is, normaalweg sal voortplant. Met elke nuwe generasie word daar uit laasgenoemdes opnuut albino's en heterosigoot-draers, benewens genotipies gesonde persone, 
gebore. Die bron van potensiële albino's bly dus behoue en kan slegs met baie klein inkremente per generasie verlaag word.

Die voorbeeld van albinisme is nie ' $n$ uitsonderlike model om die effek van seleksie teen 'n resessiewe abnormaliteit te illustreer nie. Slegs die volgende wysigings sal in die praktyk by die seleksie teen ander resessiewe genetiese afwykings in aanmerking geneem moet word: die geenfrekwensies mag hoër of laer wees as dié vir albinisme; seleksie is baie selde $100 \%$ doeltreffend (soos hierbo veronderstel); nuwe mutasies van elke genetiese siekte akkumuleer voortdurend tydens die seleksietydperk; gebalanseerde polimorfismes (voordeel van heterosigositeit) kan die seleksieprogram aansienlik belemmer. Die algemene gevolgtrekking hieruit is dat 'n effektiewe afname in die geenfrekwensie van resessiewe genetiese siektes baie millennia van volgehoue seleksie sou vereis. 'n Drastiese verlaging van die geenfrekwensie (of 'n algehele uitwissing) van resessiewe abnormaliteite sal prakties 'n onbegonne taak wees.

Gebalanseerde polimorfismes; 'n Besonder belemmerende faktor by eugenetiese seleksieprogramme is die feit dat baie van die ressessiewe faktore alleen van nadeel is wanneer hulle in die homosigotiese en nie wanneer hulle in 'n heterosigotiese toestand voorkom nie. Trouens, die heterosigotiese kombinasie verteenwoordig in hierdie gevalle die mees voordelige genotipe $\mathrm{t} o \mathrm{v}$ daardie betrokke kenmerk en gee aanleiding tot 'n gebalanseerde polimorfisme ( $\mathrm{m}$ a $\mathrm{w}$ $\mathrm{n}$ behoud van die nadelige resessiewe faktor terwille van sy heterosigootvoordeel). Die mees bekende voorbeelde hiervan by die mens is sekelselbloedarmoede en talassemie, terwyl sistiese pankreasfibrose, fenielketonurie, galaktosemie en die Tay-Sachs siektetoestand moontlik tot die minder opvallende voorbeelde van hierdie verskynsel gereken kan word. Dit mag wees dat nog baie meer gebalanseerde polimorfismes in menslike bevolkings voorkom. Eugenetiese seleksieprogramme is hier dus met 'n komplekse probleem opgeskeep wat in sy volle perspektief nog glad nie beoordeel kan word nie.

\section{Heterosigote in bevolkings}

l'en einde die effektiwiteit van seleksie te verhoog kan leoreties oorweeg word om ook die fenotipies onop- 
vallende groep van heterosigoot-draers as gedurige potensiële bron van spesifieke genetiese abnormaliteite by ' $n$ eugenetiese seleksieprogram in te sluit. Soos wiskundige afleidings aantoon, skommel die frekwensie van heterosigote t o v'n sekere afwyking ooreenkomstig die geenfrekwensie waarmee daardie spesifieke abnormaliteit binne 'n bevolking voorkom. Vir die geenfrekwensies waarmee die meeste resessiewe abnormaliteite voorkom is daar vir elke homosigoot aangetaste pasiënt soveel as 100 - 1000 fenotipies onopvallende heterosigoot-draers in die bevolking aanwesig. In 'n bevolking as geheel sal daar dus benewens die betreklik klein getal van aangetaste homosigote baie duisende heterosigoot-draers bevat wees. Vir die bekende siektetoestande sistiese pankreasfibrose, fenielketonurie en galaktosemie word byvoorbeeld geskat dat gemiddeld een uit elke 20, een uit elke 50 en een uit elke 120 persone in bevolkings onderskeidelik fenotipies onopvallende heterosigoot-draers van genoemde genetiese abnormaliteite is.

'n Besonder uitdagende navorsingspoging in die moderne menslike genetika is juis daarop gerig om die fenotipies onopvallende heterosigote te kan uitken. Danksy verfynde biochemiese tegnieke is inderdaad daarin geslaag om vir enkele genetiese siektes (byvoorbeeld by sistiese pankreasfibrose, fenielketonurie en talle andere) toetse te ontwikkel waarvolgens die heterosigote met 'n groot mate van sekerheid uitgeken kan word. Gegrond op sodanige toetse sal teoreties geëis kan word dat die eugenetiese seleksieprogram ook na fenotipies onopvallende heterosigoot-draers uitgebrei word. Met so 'n radikale maatreël kan 'n resessiewe siekte inderdaad binne 'n enkele geslag volledig, maar slegs tydelik, uitgewis word. Die proses van mutasie gaan naamlik ongedeerd voort en met elke opgroeiende geslag akkumuleer nuwe abnormale gene vir daardie pas uitgeroeide resessiewe siekte. Die eugenetiese seleksieprogram sal dus in die daaropvolgende geslagte met volgehoue intensiteit voortgesit moet word om aan die doelstelling van eugenetika sinvolheid te verleen.

\section{Die "genetiese las" van 'n bevolking}

Daar is tans ongeveer 1000 resessiewe genetiese siektes by die mens bekend. Vir elkeen daarvan is daar in ' $n$ 
spesifieke bevolking (soos hierbo aangetoon) baie duisende onopvallende heterosigoot-draers (benewens die heelwat ininder homosigoot-aangetaste pasiënte) aanwesig. Geneem oor alle bekende resessiewe siektes volg hieruit dat elke bevolking dus 'n oorweldigende getal heterosigoot-draers van alle soorte huisves. Trouens berekeninge (wat voorlopig slegs growwe benaderings is) toon dat elke individu gemiddeld nie alleen 'n heterosigoot-draer van slegs een resessiewe genetiese siekte is nie, maar van soveel as 5-8! Dit beteken dat elke mens gemiddeld 5-8 eenhede van genetiese informasie ("lethal equivalents") besit wat 'n letale genetiese siekte tot gevolg sou hê indien hy homosigoot vir slegs een van daardie genetiese faktore sou wees. 'n Individuele diagnose op hierdie vlak is feitlik onmoontlik. Slegs indien uit 'n huwelik van fenotipies onopvallende persone kinders met die een of ander resessiewe abnormaliteit gebore word, is dit die enigste aanduiding dat vader en moeder heterosigoot-draers van toevallig dieselfde resessiewe genetiese siekte is (vgl egter heterosigoottoetse). Origens is die groot aandeel en tipes nadelige resessiewe gene in elke bevolking ("genetic load" of "genetiese las") feitlik heeltemal verborge.

Verwysende na die feit dat volgehoue navorsing mettertyd heelwat meer resessiewe genetiese siektes sal uitken, volg dat die totale aandeel van alle heterosigootdraers waarskynlik aansienlik hoër moet wees as tans geskat is. By hierdie uiteensetting is daar geen aandag gegee aan die baie dominante genetiese siektes wat eers na voortplantingsouderdom tot drastiese abnormaliteite aanleiding gee nie (byvoorbeeld Huntington's chorea). Bykomstiglik moet nog baie semiletale faktore en poligeniese swakhede in aanmerking geneem word. 'n Gesamentlike evaluering van hierdie bevindinge gee weliswaar aanleiding tot die skokkende gevolgtrekking dat menslike bevolkings "deurdrenk" is met genetiese siektes en abnormaliteite. 'n Mens word gekonfronteer met die besef “. . . dass wir alle 'erbkrank' sind” (Baitsch, 1966).

III. DIE DILEMMA VAN KLASSIEKE EUGENETIKA Indien die algemene idealistiese en humanistiese motivering asook die meer konkrete doelstellings van die eugenetika argumentsonthalwe aanvaar word, dan kom die praktiese toepassing van eugenetiese maatreëls voor 
onoorkomelike probleme te staan. Die mees effektiewe metode van die klassieke eugenetika, $\mathrm{nl}$ verpligte sterilisasie (naas sekondêre metodes soos voorligting, raadgewing ens) blyk vanweë teoretiese en wetenskaplike tekortkominge tot mislukking gedoem te wees. Indien die probleme $\mathrm{m} b \mathrm{t}$ die toepassing van eugenetiese maatreëls soos hierbo bespreek in aanmerking geneem word, dan moet veral die volgende samevattende gevolgtrekkings onder oë gesien word:

(a) Die omskrywing "fenotipies gesond/normaal" (of "fenotipies siek/abnormaal") is relatiewe begrippe wat dikwels afhang van die mate waarmee omgewingsinvloede by die totstandkoming van die genetiese eienskappe betrokke is.

(b) Die genotipiese variabiliteit binne bevolkings toon kontinue oorgange. 'n Gedeelte van dié kontinue genetiese variabiliteit wat as "siek/abnormaal" beskou kan word, word danksy moontlikhede van medies-tegniese kompensasie genotipies feitlik geheel en al "genees". Die grootste gedeelte daarvan bly egter latent in bevolkings verborge en kom slegs geleidelik met betreklik lae frekwensies in homosigote tot uiting.

(c) Indien seleksie gewoonweg op die fenotipes gegrond is, sal eers na baie millennia 'n betekenisvolle vordering opgemerk kan word. Ten spyte van volgehoue streng seleksiemaatreëls oor duisende generasies sal nuwe mutasies altyd weer aanleiding tot toenames in die frekwensie van abnormale gene gee.

(d) Die teoretiese uitweg ten einde seleksie te bespoedig sou wees om dit na alle heterosigoot-draers uit te brei. Dit kom daarop neer da. n hele bevolking uitgeroei sal moet word ten einde alle genetiese siektes uitgewis te kry.

Hier is die klassieke eugenetika dus vasgevang in die dilemma van 'n reeks onmoontlike en absurde alternatiewes.

'n Teoretiese uitweg uit hierdie dilemma is om kompromieë aan te gaan. Die eugenetiese seleksieprogram 
sal afgewater moet word, daar sal prioriteite gestel moet word; op sy beurt gee dit aanleiding tot meningsverskille en nuwe probleme. Ten slotte sal dit blyk dat ook alle kompromieë ten opsigte van die tydperk van seleksie, of ten opsigte van die gedeelte van die bevolking wat betrek word ewe onaanvaarbaar en onprakties is. Dit blyk dus dat die mens met sy genetiese siektes en inherente swakhede of abnormaliteite, d w s met sy "genetiese las" ("ger.etic load") feitlik opgeskeep sit.

Die diskreditering en mislukkig van die klassieke eugenetika volg dus nie uitsluitlik uit die misbruik wat daarmee gedryf is nie en ook nie alleenlik omdat dit etiesmoreel as onregverdigbaar en as onversoenbaar met die individualistiese opvatting van ons tyd beskou is nie. Daar is mette: $t / d$ besef dat, op grond van wetenskaplike en teoretiese probleme, die klassieke eugenetika nie doeltreffend en suksesvol u'tgevoer kan word nie. Die momentum wat gedurende die eerste ielfte van hierdie eeu tot 'n ontplooiing van eugenetika gelei het. het dienooreenkomstiglik tans 'n laagtepunt bereik; vir hoe lank ..?

\section{Teenswoordige stand van eugenetika}

Voortvloeiend uit die onoorkomelike wetenskaplike probleme wat die klassieke eugenetika teëgekom het, het dit oor die afgelope dekade 'n gedaantewisseling ondergaan. Die ambisieuse programme van weleer is afgewater na 'n opsionele vakkundige diens. Hier is uit die samewerking van medici en genetici 'n nuwe interdissiplinêre gespesialiseerde en toegepaste vakwetenskap, naamlik "genetiese raadgewing" ("genetic counselling") gebore wat reeds 'n belangrike funksie (in die toekoms sekerlik nog heelwat meer) vervul. Die vakkundige diens wat hier gelewer word, soos voorligting en raadgewing, is op die individu of die individuele familie toegespits. Daarmee is die essensiële eugenetiese doelstelling, naamlik die kwalitatiewe genetiese verbetering van 'n bevolking of die mens as geheel, feitlik uitgeskakel.

Naas genetiese raadgewing as rudimentêre oorblyfsel van die klassieke eugenetika is daar egter ook 'n nuwe aktiwiteit te bespeur wat waarskynlik 'n nuwe fase inlui. Voorlopig skyn dit as sou die nuwe eugenetiese ontwikkeling nog betreklik afsydig staan teenoor die idealistiese doelstellings van die verlede. Die klem het 
nou verskuif na die fenomenale vooruitgang op die terrein van medies-genetiese tegnieke en behandelingsmoontlikhede. Dit blyk egter net 'n kwessie van tyd te wees eer dat hierdie medies-genetiese moontlikhede die klassieke eugenetiese ideale met nuwe lewe sal vervul. Die stimulus van die nuwe ongekende moontlikhede tesame met die werklike of vermeende noodsaaklikheid van optrede - wat volgens die toenemende getal van voorstaanders nou dringender as ooit is - mag moontlik aan die eugenetika ' $n$ permanente plek in ons hedendaagse samelewing toewys.

H W HITZEROTH AFRIKA-INSTITUUT 